\title{
THE ECONOMIC INFLUENCE ON CONSUMERS BUYING BEHAVIOR IN ISLAMIC COUNTRIES: EVIDENCE FROM THE COVID-19 ECONOMIC CRISIS
}

\author{
Mohammad Mushfiqul Haque Mukit ${ }^{1}$, Nusrat Jahan Nabila ${ }^{2}$, \\ Assim Ibrahim Abdel-Razzaq ${ }^{3}$, Kazi Fatema Shaznin ${ }^{4}$ \\ date of paper receipt: \\ 07.12.2020. \\ Original Article \\ date of sending to review: \\ 10.12.2020. \\ doi: 10.2478/eoik-2021-0003 \\ date of review receipt: \\ 25.12.2020. \\ UDK 347.447.63:[616.98:578.834
}

${ }^{1}$ Department of Economics, Jahangirnagar University.1342, Savar, Dhaka, Bangladesh

Department of Business Administration, East West University, A/2 Jahurul Islam Ave, Dhaka 1212, Bangladesh, e-mail: mushfiq.mukit@gmail.com

${ }^{2}$ Department of Business Administration, University of Asia Pacific, Green Road, Dhaka 1205, Bangladesh

${ }^{3}$ Accounting \& Finance Department,Prince Mohammad Bin Fahd University, Al-Khobar, Kingdom of Saudi Arabia (KSA)

${ }^{4}$ Department of Environmental Management, University of the West of England - UWE Bristol., Bristol, United Kingdom

\section{ABSTRACT}

The Covid-19 pandemic has ushered in a new age in the world. We are still grappling with the implications in various areas of our everyday lives. The impulsive buying habits of consumers, the supply chain, and the whole industry are not exceptions. Consumers and supply chains were both unprepared during the early stages of the novel coronavirus pandemic. The procurement of utilitarian products was referred to as panic buying. The study examined using exploratory studies on several individuals in the eight selected Islamic countries who have been panic buying in coronavirus-affected areas and have faced regional constraints. The data apply on exploratory factor analysis (EFA) in eight selected Islamic countries, three hundred sample finally selected, and a good number of volunteers supported in this study. The results have shown that a drastic financial effect on the economy where purchasing power and remittance inflow declined, inflation goes up and precaution for lockdown, whereas impulsive buying goods tendency increased due to misinformation, and panic buying immensely impact in the economy. The decision-making process has shifted, preventing financial burdening, rising saving patterns, and unwelcoming unhealthy consumption. Moreover, visible psychological distress, depression, anxiety, and posttraumatic stress. These studies concluded with a policy recommendation providing the results.

\section{Keywords:}

Consumer, Panic Buying, Covid-19, Depression, Economy, Health, Lockdown, and Islamic Countries.

JEL Classification: C23, C51, D12, M31, G2, G4, I1, M2 


\section{INTRODUCTION}

The effect of the coronavirus (Covid-19) on the consumer spending in the eight Islamic countries is investigated in this report. The Covid-19 virus has spread around the globe and has dominated the news headlines since the first death in Wuhan, Hubei, China in early January 2020. The virus's initial outbreak and spread were limited to China, but it quickly spread across Asia, Europe and the rest of the world within five months. More than 452,131 people died worldwide by the end of June 2020. (WHO, 2020). Covid-19 was listed as a new challenge in 2015, following the SARS epidemic in China in 2002, the Ebola epidemic in West Africa, and the MERS epidemic in 2015 (ibid). First, known defense against the virus was lockdown. A third of the global population followed restrictive movement by the first three months of 2020 (Bloomberg News, 2020). As peoples' lives were prioritized over their economic activities, the extreme interconnectedness of the global economy immediately resulted in quarantine at a global level (Chinazzi et al., 2020; Hedgecoe et al., 2020.).

Covid-19 triggered a dramatic drop in household consumption due to a major global halt in daily economic activities. The global population's life and consumption styles have reportedly changed as a result of the "New Normal" (Criteo Coronavirus Survey, 2020). As a result, demand for consumer products fell rapidly (Szymkowski, 2020), resulting in factory closures and major consequences for global consumption, trade, retailing, and banking (Feng and Fay, 2020; Evans, 2020; Dooley et al., 2010; Foxall, 1979; Lamming, 2000). Consumer behavior research aims to better understand how customers make decisions and to define the characteristics of individual consumers and groups in order to better understand what they want and need (Anderson et al., 2005). Individual and collective consumption buying intentions have a significant effect on purchasing decisions, which can be spontaneous or triggered by a shock (Beatty and Ferrell, 1998). In this paper, we investigate consumers' impulsive buying responses during the outbreak. Although researchers are yet finding a robust connection between consumer purchase behavior and the occurrence of a pandemic, Based on positive decision-making, we can suggest that customers are less likely to buy offers from industrial suppliers during an unceasing coronavirus pandemic, particularly in the case of expensive offers in countries with the low long-term orientation, and high uncertainty (Hofstede \& Minkov, 2010; Hofstede, 2001).

Remarkably, Covid-19 may inadvertently contribute to development, maybe on a temporary basis. These include the achievement of the Sustainable Development Goals (United Nations SDG 20152030), SDG 2 (End Hunger) SDG 12 (ensuring sustainable consumption and production) and the objective of diminishing food waste per capita by 2030. Around a third of the world's food, about 1.3 billion tons, wasted per year (FAO, 2011), contributing to already worse economic, environmental and social impacts Food losses and industrial waste amounted to approximately $\$ 680$ billion in developing countries and $\$ 310$ billion in developed countries, respectively (FAO, 2013).

The spread of the Covid-19 forwards a significant change in the purchasing habits of consumers, which is of great importance for traders of different brands from diverse industries and regions (Murphy et al., 2020). A summary of the impact on selected economies presented in Table 1.

Egypt's economy is based primarily on tourism and remittances, both of which have been severely injured by the pandemic (El Dahshan, 2020; Emam, 2020). Egypt's informal economy accounts for half of the country's GDP, which would be negatively impacted. Egypt has reported a loss of $\$ 2.8$ billion as a result of the economic blockade. Malaysia is forecast to lose about $\$ 10.50$ billion, the most of the countries studied (Table 1), with Saudi Arabia ( $\$ 9$ billion) and Pakistan ( $\$ 5$ billion) following closely behind. Saudi Arabia would have to forego a significant amount of income from Hajj pilgrims as a result of the ban on mass gatherings. A drop in oil prices will only add to the crisis (McIntosh, 2020). 
Table 1. Economic overview during COVID-19 in selected countries

\begin{tabular}{|c|c|c|c|}
\hline Country & Lockdown Loss (\$) & Stimulus Packages & $\begin{array}{l}\text { Remittance Inflow } \\
\text { April-2020 }\end{array}$ \\
\hline Bangladesh & $\$ 1.4$ billion & $\$ 11.90$ billion & $\$ 1290$ million \\
\hline Egypt & $\$ 2.8$ billion & $\$ 10.0$ billion & $\$ 6000$ million \\
\hline Indonesia & $\$ 1.9$ billion & $\$ 47.6$ billion & $\$ 2575$ million \\
\hline Jordan & $\$ 1.5$ billion & $\$ 775.75$ billion & $\$ 8462$ million \\
\hline Saudi Arabia & $\$ 9$ billion & $\$ 13.32$ billion & $\$ 6800$ million \\
\hline Malaysia & $\$ 10.50$ billion & $\$ 68.0$ billion & $\$ 5500$ million \\
\hline Pakistan & $\$ 5.0$ billion & $\$ 7.2$ billion & \$958.91million \\
\hline Turkey & $\$ 3.5$ billion & $\$ 38.7$ billion & $\$ 5438.65$ million \\
\hline
\end{tabular}

Note: World Bank first quarter projected GDP lockdown loss and received remittance in April-2020.

Source: Author adopted \& Data Processed 2020 (approximated)

During the Covid-19 recession, the Indonesian government estimates that between 1.1 million and 3.78 million Indonesians will become poor, and between 2.9 million and 5.2 million will lose their employment (New Straits Times, 2020). Economic growth has most likely been at its slowest since the financial crisis of 1998. As a result, the recently proposed economic stimulus plan boosts consumer and corporate buying power. Indonesia's economic growth is projected to remain above zero percent as a result of the opportunity. According to Selva Demiralp (2020), the pandemic has had a detrimental and vulnerable impact on the Turkish supply chain economy, with the majority of non-essential sectors having to further halt production as infected citizens withdraw from the workforce and are unable to engage in production.

Our study carries significant implications for brands attempting to differentiate their offers in the post pandemic periods. Given the economic and social challenges. Brands can develop deeper customer relationships by being reliable source of accurate or consumer-oriented information in times of uncertainty. This study investigates the financial effect of Covid-19 on the economy by integrating important questions that address impact of Covid-19 on financial health at the personal and household level with questions on the respondents' perceptions on potential purchase intention. Data from three hundred respondents residing in Bangladesh, Egypt, Indonesia, Jordan, Saudi Arabia, Malaysia, Pakistan and Turkey were analyzed. The findings point to a significant shift in Muslim consumers' buying intentions in the chosen region. As a result, brands marketing to these consumers should have to make major changes to their business models. Economic data indicates a substantial drop in demand, with the added drawbacks of panic buying and a rise in the rate of inflation. To mitigate digital waste and health risks, we propose that the expansion of technology-intensive selling techniques be accompanied by an environmentally sustainable manufacturing process.

\section{LITERATURE FRAMEWORK}

\subsection{IMPULSE BUYING AND FINANCIAL IMPACT OF COVID-19}

Murphy (2020) discusses the factors that influence consumer decision-making during a pandemic. Adaptive decision-making mediates behavior change, which is affected by five factors: physical background, social context, processing, motivation, and capacity. Given the five individual and contextual characteristics, the model reflects the trend of rapid adaptation by consumers. A model of technology adoption or a theory of expected action are two other theoretical models that can be 
applied to the intent of the purchase (Davis et al. 1989; Ajzen, 1991). The impulse buying tendency (IBT) is characterized by a proclivity for making sudden and spontaneous purchases. According to Beatty and Ferrel (1998), a seller with a higher impulsive selling proclivity is more likely to feel a greater urge to buy impetuously and tends to act more frequently. Mogelonsky (2020) claimed that Covid-19 is considered the 'Next to Normal', as this pandemic will affect lives in coming years to come. Previous studies on pandemics portray the importance of impulse buying. Let alone the cost to the economy, impulse buying in previous cases, including the Spanish flu (Almond, T. 2006; Garret, A.T. 2008; Karlsson, Nilsson and Pichler, 2014; Guimbeau, Nidhiya and Aldo, 2020); avian influenza (Bruns et al., 2006); the SARS (Chou et al., 2004; Hia et al, 2004; Mukit, Nabila, Islam, \& Abdel-Razzaq, 2020; Lee and McKibbin, 2005; Liu et al, 2005; Brahmbhatt and Dutta, 2008; Keogh-Brown et al., 2008); the swine flu (Rassy and Smith, 2013); and the Ebola (Kostova et al. 2004), have contributed significantly to our learning on impulse buying and selling. The specificity of the impact on medical sciences and the healthcare industry has been noteworthy (Meltzer et al., 1999; Brainerd \& Siegler, 2003; Bootsma, \& Ferguson 2007; Karlsson, T. et al., 2014; Correia et al., 2020).

Covid-19 is primarily characterized as a disruption. It will end one day, but not without severe economic, emotional, and social consequences. It will one day be over but at the price of extreme economic, emotional and social consequences.

Some manufacturing and consumer industry industries, including the travel and tourism market, maybe completely and partially wiped out globally, with major negative outcomes for countries dependent on these sectors for their bottom line (Luca Fornaro \& Martin Wolf, 2020; OECD, 2020). Inclusive adverse effects on the economy are likely to rely on the scale of investment in public health, especially in less developed countries (McKibbon and Fernando, 2020a, 2020b). The impact, however, is expected to be different for different industries. The service sector is expected to experience a longer-term impact compared to the manufacturing sector (Fernandes, 2020). Since the start of Covid-19, stock market volatility, media analysis of financial uncertainty, and subjective uncertainty in business expectation surveys have increased dramatically (Baker et al., 2020b; Leduc and Liu, 2020). For example, in the fourth quarter of 2020, Baker et al (2020b) predicted that the United States' GDP could fall by about 11 percent.

Vishnu and Raheem (2013) suggest that Pakistani consumers are more likely to buy impulses when they see free product offerings and price discounts on consumer goods. Income levels, stores, and visual marketing carry significant influence on consumer behavior, especially in a wellequipped, pleasant, and calm shopping milieu and a colorful environment. In addition, between men and women, there is a disparity in impulsive purchasing behavior. Rashmi (2014), Thakor and Prajapati (2012), Verma and Verma submitted similar results (2012). Impulse purchase in generally unplanned. Hence, travel and tourism sectors present varied impact during the time of crisis as the crisis may create opportunities in terms of discounts or higher cost due to restriction (Puccinelli et al., 2009; Mukit, 2020; Gutierrez, 2004; Thomas and Garland, 2004; Berné et al., 2001; Thomas and Garland, 1993; Heckhausen and Gollwitzer, 1987; Iyer and Ahlawat, 1987).

These are the times when buyers consider the price and availability of products. Deloitte (2020) has reported that a pandemic offers the possibility of diversifying the capabilities of a business. Nevertheless, more virtual functionality can also increase network risk. However, adding virtual functionality can also proliferation the network risk? The consumer experience has also shifted, pushing consumers to use digital tools that could speed up digital transformation and implementation. Flexibility in the supply chain has already begun, and forward-looking businesses should aim to diversify the risks of vendors and other third parties. 
The customer experience has also changed, with customers being forced to use digital platforms, which could accelerate the digital transformation and implementation. Flexibility in the supply chain has already inaugurated, and forward-looking businesses should aim to diversify the risks of vendors and other third parties. Investors are taking time to understand and analyze the risk profile, business opportunities, and financial results, how does reflects on the supply chain. Another market analysis company Accenture (2020) has reported that consumer (buying) attitudes will change permanently. Consumers will prioritize 1) basic necessities 2) local products, and 3) electronic orders for a long time even after the pandemic is over. Companies in the business of virtual workplaces, including games and digital connectivity, will see a sharp rise in their sales and market size. To reduce the cost of the raw materials and labor supply, large manufacturing outlets will digitalize their workforce or will run for countries with low-cost labor located in Africa, South Asia and South America. Mahmood (2020) supported this view and reported some relatively uncertain but progressive message for the readymade garments industry in Bangladesh.

The above literature leads us to two major propositions. Firstly, there is a strong product cluster that caters to the need of impulsive buyers during the crisis time. The clusters can be used to introduce market and advertisement strategies. Secondly, demography will play an important role in explaining the change in impulse buying during crisis time. Consequently, companies will accommodate demographic profiling in their strategies in order to stay relevant in business.

In the following sections, we explain how this study accommodates these propositions to test them using survey data from selected eight Islamic countries. Results of the product and demographic clustering will help us reach a significant conclusion for the Muslim consumers and their impulse buying habits during the pandemic. The panic buying by UK shoppers left the shelves of thousands of shops free of important household products, including pasta, rice, sanitizers, and toilet paper, as Cogley (2020) reported. Cogley (2020) attributed this behavior to "social influence" and "the theory of social evidence." The author also found out that a number of social media sites (e.g. Twitter and Facebook) are the main sources that fuelled the rush among individuals to stock simple household items, according to some experts. Scientists and other public health professionals often use social media to communicate directly with the public or to debate embryonic science, while thousands of people spread sensationalism, rumors and other types of misinformation (Dela, 2020). This can be obscured by the philosophy of risk culture, which offers an explanation of how society or individuals respond to unpredictable conditions or risk. 
Table 2. Some Selected Authors Review \& Findings

\begin{tabular}{lll}
\hline Author & Title & Methodology \& Findings \\
\hline & $\begin{array}{l}\text { Unusual purchasing } \\
\text { behavior during the } \\
\text { early stages of the }\end{array}$ & \\
Gamma et al. & $\begin{array}{l}\text { COVID-19 pandemic: } \\
(2020)\end{array}$ & $\begin{array}{l}\text { Theory: RANAS model } \\
\text { The stimulus- } \\
\text { organism-response } \\
\text { approach }\end{array}$ \\
&
\end{tabular}

\begin{tabular}{|c|c|c|}
\hline $\begin{array}{l}\text { Al-Debei et al. } \\
\text { (2015) }\end{array}$ & $\begin{array}{l}\text { Consumer attitudes } \\
\text { towards online } \\
\text { shopping: } \\
\text { The effects of trust, } \\
\text { perceived benefits and } \\
\text { perceived web quality } \\
\text { (Jordan) }\end{array}$ & $\begin{array}{l}\text { Factor analysis and structural path model analysis were used to assess the study } \\
\text { model's hypothesized relationships. This study's empirical findings suggest that } \\
\text { confidence and perceived advantages influence customer attitudes towards } \\
\text { e-commerce }\end{array}$ \\
\hline
\end{tabular}

\section{Unusual purchasing}

behavior during the

A.K.M. Najmul early stages of the

Islam, Ali Farooq, COVID-19 pandemic:

Amandeep Dhir

(2020)

The stimulus-

organism-response

approach
The observed consumer behavior was directly related to anticipated time spent in self-isolation, as evidenced by self-intention to self-isolate and intention to make unusual purchases. Exposure to online information outlets also resulted in increased information overload and cyberchondria, according to the findings. A total of 211 finish people completed the survey.
Did location-based

Laato et al. (2020) games motivate players to socialize during COVID-19?
Acceptance of government efforts to combat the pandemic and perceptions of the pandemic's seriousness are linked to the implementation of prescribed health behaviors. Sample size is 855 . Smart PLS used to analyze this study.

\section{Michael Keane, Timothy Neal (2020)

Kelly S. Clemens, John Matkovic, Kate Faassec \& Andrew L. Geers (2020)

Erpeng Wang,
Ning An, Zhifeng
Gao, Emmanuel
Kiprop \& Xianhui
Geng (2020)

\section{Determinants of} safety-focused product purchasing in the United States at the beginning of the global COVID-19.
Consumer food stockpiling behavior and willingness to pay for food reserves in COVID-19
Worry increased product purchase for men who were initially low in worry, but not for women, according to a study. This research reveals risk and safety-related actions, with implications for determining factors. There were 344 samples considered.
Soniya Billore,

Tatiana

Anisimova (2021)
A variety of motivations and subjective risk perceptions drive food stockpiling behavior. Consumers who are female, have a high education level, and have a high income are more likely to store greater quantities of food, but their ability to pay for fresh food reserves is dictated by their income.

\section{Ansima}

Panic buying research: A systematic literature review and future research agenda
Callahan's 4W (2014) analysis structure and Paul and Rosado Serrano’s (2019) TCCM system were investigated in this report. Policymaking and governance were listed as areas where current panic buying publications are scattered across multiple disciplines.
Do social media platforms develop

Naeem, M. (2021) consumer panic buying during the fear of Covid-19 pandemic?
Social influence and social acknowledgement play a role in panic buying as a form of persuasion. People trust their close friends' buying advice because they believe their friends are honest and their feedback will help them make the best purchasing decisions. A total of 34 samples were considered.

\section{* There were Insufficient study materials, so considered related relevant articles. \\ Source: Author Adopted}


The key aim of this thesis is to investigate how the panic buying normative behavior of customers has a financial impact; thus, it considers social evidence theory as the most suitable and applicable theory in this regard since the panic behavior of consumers is a socially created phenomena focused on the views of analysts, sensationalism, and disinformation spread by social media users (SMU).

Figure 1. Consumer Panic Purchasing Process for Social Media Users (SMU)
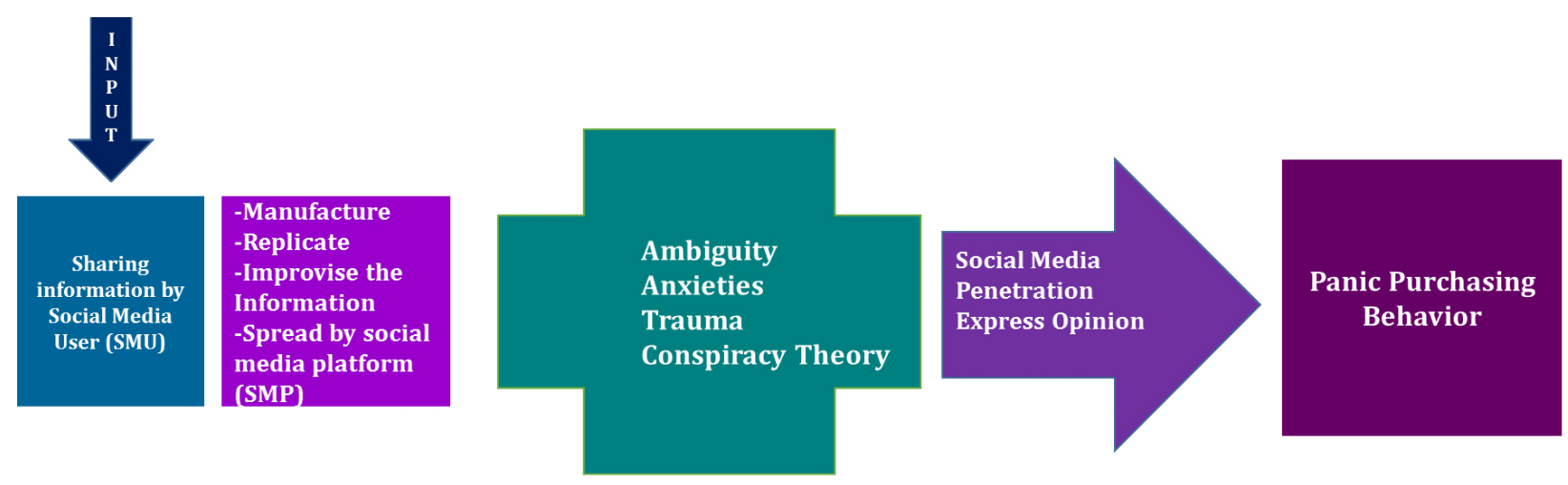

Source: Author Adopted

\section{RESEARCH DESIGN AND DATA ANALYSIS}

The purpose of this research is to develop Muslim consumers' impulsive buying response in the case of the "Next Normal" case of the Covid-19 pandemic in selected eight Islamic countries (Bangladesh, Egypt, Indonesia, Jordan, Saudi Arabia, Malaysia, Pakistan and Turkey). Thus, to further explore of this research following hypothesis is formulated:

$\mathbf{H}_{\mathbf{1}}$. Reviewing the trend analysis of Muslim consumers' impulsive buying pattern in the eight selected Islamic countries during the degree of awareness towards Corona virus.

$\mathbf{H}_{\mathbf{2}}$. To study the Muslim consumer's impulsive financial spending intentions to stock goods, period of the Covid-19virus in the eight selected Islamic countries over the next three months of lockdown.

$\mathbf{H}_{3}$. To analyze the impulse buying intentions of Muslim consumers compared to the traditional purchasing channel and to the online platform prefer brands in the eight selected Islamic countries.

Quantitative approach has adopted in this study. In particular, this study used a questionnaire to reach selected Islamic countries, especially the Muslim consumers in the capital cities. Some of my friends supported us to collect this data meticulously. Questionnaire tested by research scholars and ten brand managers in corporate sectors, to ensure a correct conceptual structure. This study uses a quantitative research method and statistical analysis software (SPSS) version 26. This allows the researcher to compile the answers one after the other. The questionnaires prepared by the researchers help the researcher to display the data correctly.

The analysis was carried out using a self-directed questionnaire. During the first two weeks of the COVID-19 pandemic (lockdown began on 19 March 2020 in Bangladesh, 14 April 2020 in Pakistan, 21 March 2020 in Turkey and 9 March 2020 in Saudi Arabia), it was created and controlled in English from 29 March to 29 June 2020, surveyed via the Google Document survey website. To survey these study individual country representatives help me to find the authentic data. After completion the survey, fact check with incumbents survey leader. The respondents were engaged in this survey enthusiastically.

The analysis starts with an online zoom discussion among the focus group. The analysis starts with 
an online zoom discussion among the focus group. The eight selected countries, we had volunteer those who helped us to collect the survey respondent's data. It continued with an online Google. com offered survey form supports. We applied a structured questionnaire among the respondents. From the Google survey list, we received primary data from 383 respondents. Then we rescind, those respondents who had left unanswered or incomplete responses. Finally, we worked out among the 300 data which we applied in our entire study. We shared our random survey links on WhatsApp study groups, Facebook Research Hub groups, and other social platform groups. A few enthusiastic people from various regions volunteered to assist us. We chose several Islamic countries because the month of Holy Ramadan fell during that period in 2020. This month, Muslim people are generally making a lot of purchases for households. So, if we start our survey analysis on the pandemic and the month of Ramadan, we could get some interesting results. Furthermore, most Arab countries are well-known for their petro-dollar and tourism destinations, which are the second and third most lucrative sources of revenue after remittance and trade. It is very simple to determine how economic bubbles affect these countries.

So, the study consisted of 300 participants ranging from 18 to 60 years of age (mean=2.10; $\mathrm{S} . \mathrm{D}=$ 0.542), $49.7 \%$ were female and 50.3\% were male. Respondents Household income (Mean=2.02; S.D. $=1.345$ ) and $70.7 \%$ were the eight Islamic countries city dwellers and $29.3 \%$ were outside the city of the eight Islamic countries. This research has measured the main skeleton applying multi-item scales. In addition to personal questions and "yes or no," all other questions were formulated on a Likert scale of five points and ranged from one question ("reduce a lot") to five questions ("Increase a lot"). The demographic variables selected by the investigator reflect the demographic information of the selected respondents, such as gender, age group, income and occupation. It contains the comprehensive data of the respondents chosen by the investigator. The researcher is permitted to recruit the frequency of male and female respondents as well as the individual percentage of them. Demographic characteristics selected by the researcher that reflect demographic information such as gender, age group, income and occupation of the respondents selected. It includes descriptions of the participants chosen by the investigator. The researcher has the option of including both the frequency and the personal percentage of the male and female interviewed.

Table 3. Demographic Status in the selected 8 Islamic Countries capital and outside the capital city respondents

Selected Islamic Countries Respondents Profile $(\mathbf{n}=300)$

\begin{tabular}{lll}
\hline Gender & Frequency & Percent \\
\hline Female & 149 & 49.7 \\
\hline Male & 151 & 50.3 \\
\hline Age Group & \\
\hline below 24 & 30 & 10 \\
\hline $\mathbf{2 5 - 3 5}$ & 209 & 69.7 \\
\hline $\mathbf{3 6 - 4 5}$ & 61 & 20.3 \\
\hline Location & \\
\hline City Dwellers & 70.7 \\
\hline Outside Dwellers & 212 & 29.3 \\
\hline Your household income (monthly) & \\
\hline Decrease a lot & 147 & 49 \\
\hline Decrease Slightly & 92 & 30.7 \\
\hline Increase slightly & 31 & 10.3 \\
\hline Increase a lot & 30 & 10
\end{tabular}




\begin{tabular}{lll}
\hline Occupation & Frequency & Percent \\
\hline $\begin{array}{l}\text { Craftsmen, traders, entrepreneurs, } \\
\text { Freelancer }\end{array}$ & 117 & 39 \\
\hline
\end{tabular}

\begin{tabular}{|c|c|c|}
\hline $\begin{array}{l}\text { Managers, Executives, Public (Grade } \\
1-12 \text { ) and Private professional's }\end{array}$ & 141 & 47 \\
\hline Others Profession & 42 & 14 \\
\hline \multicolumn{3}{|l|}{ Household income (monthly) } \\
\hline Less than $\$ 485$ per month & 147 & 49 \\
\hline$\$ 485$ to 1455 & 92 & 30.7 \\
\hline$\$ 3031$ above & 31 & 10.3 \\
\hline Not relevant for me & 30 & 10 \\
\hline \multicolumn{3}{|l|}{ Number of persons in the household } \\
\hline 1 & 16 & 5.33 \\
\hline 2 & 38 & 12.67 \\
\hline 3 & 54 & 18 \\
\hline 4 above & 192 & 64 \\
\hline
\end{tabular}

Source: Author Adopted

Table 4. Reliability Test

\begin{tabular}{ccc}
\hline \multicolumn{3}{c}{ Reliability Statistics } \\
\hline Cronbach's & Cronbach's Alpha & N of Items \\
Alpha & Based on Standardized & \\
0.86 & 0.889 & 47 \\
\hline
\end{tabular}

Source: Author Adopted

The reliability test allows the researcher to identify or not the reliability of the variables. The researcher uses this process to measure the consistency of the research process. Based on the data collected, Cronbach's alpha (1954) appears to be less than 1.00 and close to it. For this reason, the positive hypothesis developed by the researcher is selected by rejecting the null hypothesis.

\section{KAISER-MEYER-OLKIN AND BARTLETT'S TEST}

Table 5. Kaiser-Meyer-Olkin and Bartlett's Test

\begin{tabular}{lc}
\hline \multicolumn{2}{c}{ KMO and Bartlett's Test } \\
\hline Kaiser-Meyer-Olkin Measure of Sampling & 0.622 \\
Adequacy. & \\
Bartlett's Test of Sphericityprox. Chi-Squa: & 371.491 \\
df & 10 \\
Sig. & 0 \\
\hline
\end{tabular}

Source: Author Adopted, Data Processed 2020.

In our correlation matrix, there are a number of correlations greater than 0.3 , which indicates that 
factor analysis is appropriate here. In our study we applied the Kaiser-Meyer-Olkin Measure of Sampling Adequacy (KMO) and Bartlett's Test how adequate our sampling measurement and we found optimistic relevance and very satisfactory result. Usually $0<\mathrm{KMO}<1$. And if $\mathrm{KMO}>0.5$, the sample was considered adequate. Here $\mathrm{KMO}=0.622$, which indicates that the sample is adequate and we can proceed with the factor analysis. The approx. Chi-Square is 371.491 with 10 degrees of freedom. Here, with a significance level of $95 \%, \alpha=0.05$. The p-value (Sig.) is $.000<0.05$, so the factor analysis is valid. 
Table 6. Rotated Component Matrix

\begin{tabular}{|c|c|c|c|c|c|c|}
\hline \multirow{2}{*}{ Rotated Component Matrixa } & \multirow[b]{3}{*}{1} & \multirow[b]{3}{*}{2} & \multirow[b]{3}{*}{3} & \multirow[b]{3}{*}{4} & \multirow[b]{3}{*}{5} & \multirow[b]{3}{*}{6} \\
\hline & & & & & & \\
\hline & & & & & & \\
\hline Personal-care products & 0.854 & & & & & \\
\hline Online learning & 0.834 & & & & & \\
\hline Books/magazines/newspapers & 0.828 & & & & & \\
\hline Entertainment at home & 0.814 & & & & & \\
\hline Non-food child products & 0.812 & & & & & \\
\hline Impulsive Buying Intention next 3 month & 0.808 & & & & & \\
\hline $\begin{array}{l}\text { How long do you believe your personal/household } \\
\text { finances will be impacted by the COVID-19 } \\
\text { situation? }\end{array}$ & 0.804 & & & & & \\
\hline Home rentals & 0.782 & & & & & \\
\hline Pharma & 0.775 & & & & & \\
\hline Fitness equipment at home & 0.662 & & & & & \\
\hline Home purchases & 0.613 & & & & & \\
\hline Consumer electronics & 0.611 & & & & & \\
\hline New clothes for Eid & & 0.943 & & & & \\
\hline News on TV Channels & & 0.835 & & & & \\
\hline Video Games & & -0.733 & & & & \\
\hline $\begin{array}{l}\text { Consumer Buying Behavior spending on } \\
\text { COVID-19 time }\end{array}$ & & 0.720 & & & & \\
\hline Reading Print Newspapers & & 0.700 & & & & \\
\hline Tobacco & & 0.697 & & & & \\
\hline Special occasion buying (Eid) & & 0.677 & & & & \\
\hline Special occasion grocery - EID & & 0.567 & & & & \\
\hline $\begin{array}{l}\text { Streaming Services (e.g., Netflix, Amazon Prime, } \\
\text { etc) }\end{array}$ & & & 0.934 & & & \\
\hline News online & & & 0.858 & & & \\
\hline $\begin{array}{l}\text { How much expect to Impulsive buying during } \\
\text { pandemic? }\end{array}$ & & & 0.830 & & & \\
\hline Reading for personal interest and/or growth & & & 0.792 & & & \\
\hline Entertainment on TV Channels & & & 0.773 & & & \\
\hline Working from Home & & & 0.740 & & & \\
\hline Family Health Maintain & & & 0.787 & & & \\
\hline Adverse Physiological Impact, Violence & & & 0.718 & & & \\
\hline Demographic Status & & & & 0.932 & & \\
\hline Your household income (monthly) & & & & 0.903 & & \\
\hline Grocery & & & & 0.732 & & \\
\hline Gym & & & & 0.502 & & \\
\hline Skin care \& makeup & & & & & 0.692 & \\
\hline Local travel & & & & & 0.692 & \\
\hline Furnishings \& appliances & & & & & 0.658 & \\
\hline Food takeout \& delivery & & & & & 0.653 & \\
\hline International travel & & & & & 0.530 & \\
\hline Footwear & & & & & & 0.873 \\
\hline Branded Food Item & & & & & & 0.872 \\
\hline Apparel & & & & & & 0.739 \\
\hline Accessories & & & & & & 0.739 \\
\hline
\end{tabular}

Extraction Method: Principal Component Analysis.

Rotation Method: Varimax with Kaiser Normalization.

A Rotation converged in 14 iterations.

Source: Author Adopted, Data Processed 2020. 
The consumer never experienced about pandemic largely. So, group of people though food and grocery available, but they didn't care about supply chain system. Though the experiment of the results of the items that are included in each component suggests common themes that the components represent. The first component seems to represent Personal-care products. The second component seems to represent the new clothes for Eid (while lockdown just started that time was Muslim's religious festivals). The third component seems Streaming Services (e.g., Netflix, Amazon Prime, etc.). The fourth component seems to Grocery items. The fifth component seems to represent the Skin care \& makeup. The sixth component seems to represent the Footwear.

Panic buying is, in particular, a customer reaction in order to reduce perceived risk. In making chIslamices, consumers are affected by uncertainties that pose risks, according to the definition introduced by Taylor (1974).

\section{RESULT AND DISCUSSION}

Analysis of the above data shows that a negative impact has been identified for the FMCG, beautification items and positive response achieved for media entertainment products, electronic gadgets and other business in the eight selected Islamic countries in following the COVID-19 outbreak and lockdown. The perceived negative impact affects both sales and customers' purchasing intentions. The survey covered consumers outside the capital of the eight Islamic countries where 300 consumers responded to the survey. The confidence interval and the margin of error for this study were $95 \%$ and $5 \%$, respectively.

Quantitative measurements of the validity and reliability of the systems were added to the measurement model. This study indicates adequate reliability since the alpha value of the Cronbach was 0.86 which was above the 0.7 reasonable maximum. The C.R differed by 0.889 in terms of convergence validity, indicating that all the structures met the recommended criterion of at least 0.6 .

The Kaiser-Meyer-Olkin and Bartlett test helps to measure the relevance of the data for factor analysis. This test allows the researcher to measure the sampling power of the model for each variable. Here $\mathrm{KMO}=0.622$, Sig. the value is 0.00 and the chi-square is approximately 371,491 , which reflects both a well-deserved and positive presentation of the data. Showing that with our sample, the PCA was viable (Dziuban and Shirkey, 1974); the positive hypothesis chosen by the investigator must be taken into account by rejecting the null hypothesis. Finally, the original TPB model and the customized TPB models used in this study, which were adapted and developed, successfully explained the impulsive response of consumers to the COVID-19 pandemic, which represented $84.317 \%$ of the variance.

According to Bangladesh Bureau of Statistics (BBS) (2020), at the start of FY2020, inflation was around 5.48\%, eventually reaching 5.61\% in May F2020, which also shows that consumers impulsive buying are negative. The poverty rate is expected to increase by about 35\% in FY 2020, while the consumption and income gaps have widened in Bangladesh. Whereas in, Pakistan Bureau of Statistics (PBS) Annual consumer inflation fell to 8.5\% in April, from an 8-month low to 10.2\% in March 2020, generally inflation fall owing to lower energy prices, but the drop in consumer demand following the lockdown gives a pungent experience in economic picture with the first signs of inflation. Same situation occurred in Indonesia, Egypt and Jordan.

In this figure 1, reason of COVID 19 pandemic highest GDP reported in Egypt nearly 2 percent in the first quarter of 2020f, Bangladesh obtained approximately one percent of the second spot. The 
lowest (negative) GDP position is held by Turkey and Saudi Arabia. And, Indonesia has stayed at zero GDP.

Figure 1. First quarter GDP of $2020 \mathrm{f}$
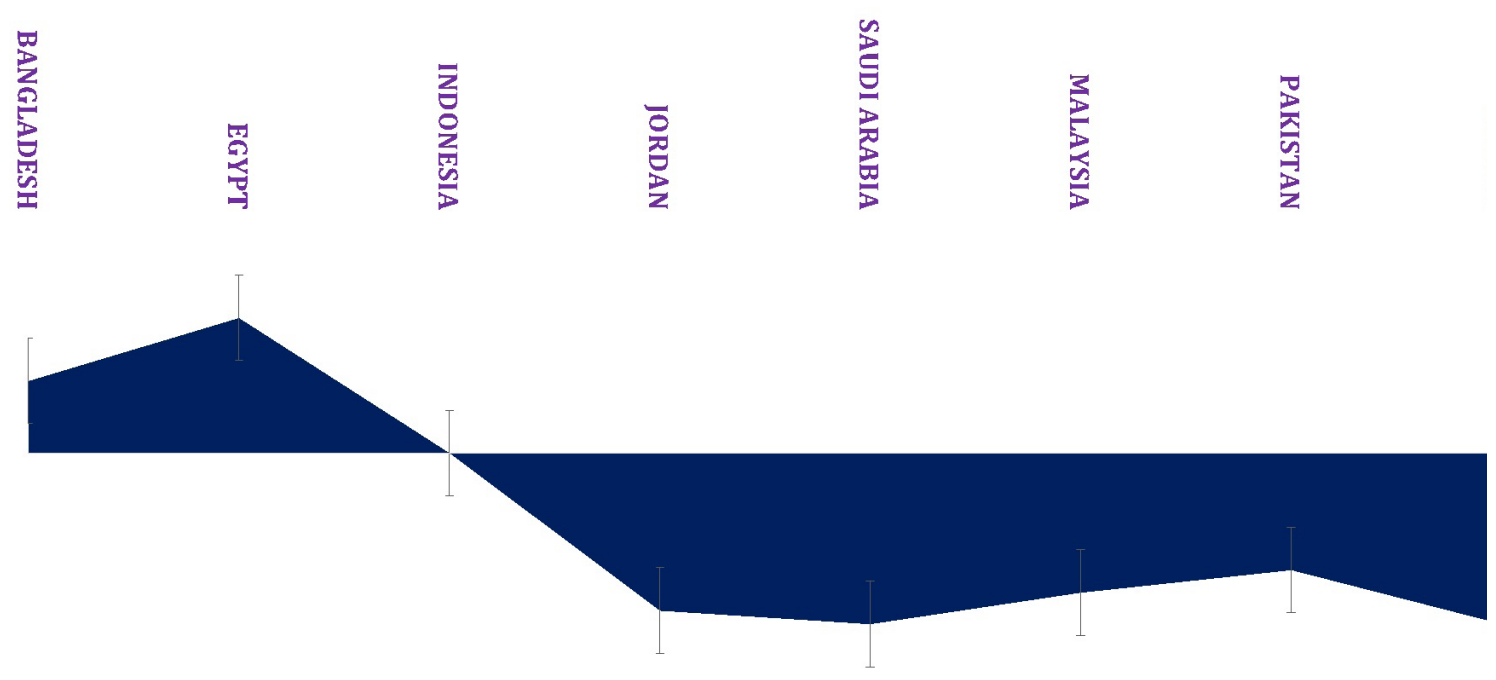

OIC Countries

Source: World Bank

Figure 2. Remittance Inflow in April-2020

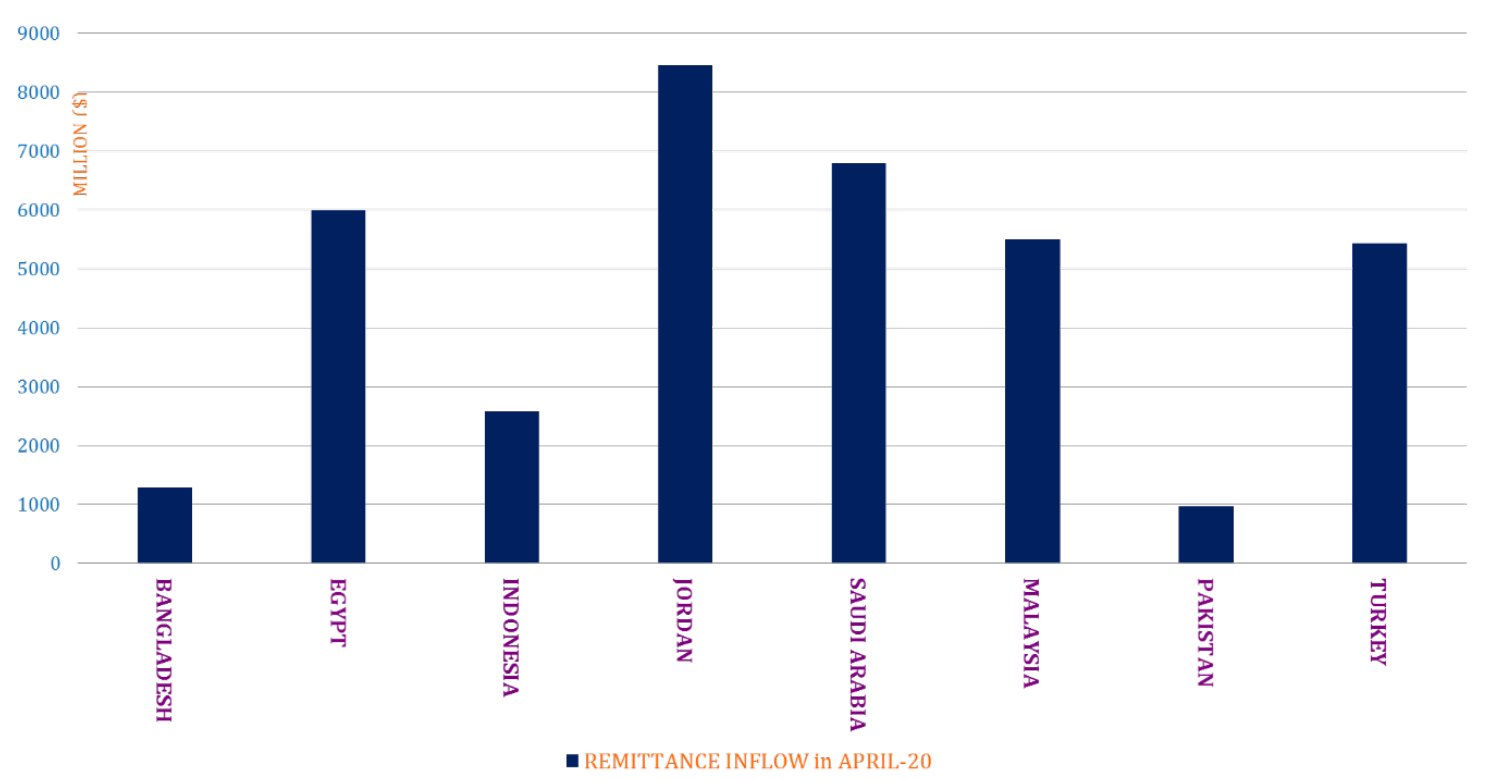

Source: Market Intelligence \& Author Adopted

In figure 2, Jordan received the highest amount of remittance, which is almost $\$ 8.2$ million, in the span of the first quarter of the pandemic remittance inflow in April-2020, and Pakistan received the lowest amount of remittance, which is around \$1 million. Nearly \$6 million was received to Egypt, Malaysia and Turkey. The kingdom of Saudi Arabia secure second highest. 
Figure 3. Descriptive Statistics of Islamic Countries

\section{DESCRIPTIVE STATISTICS}

How long do you believe your personal/household finances will be impacted by the COVID-19 situation?

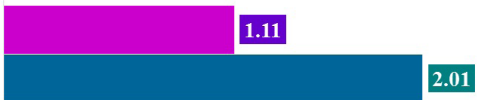

Predict to Impulsive buying during pandemic

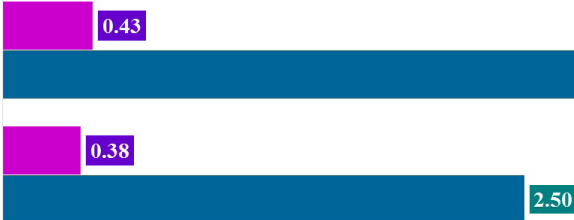

Impulsive Buying Intention in next 3 month

Consumer Buying Intention on COVID-19 time

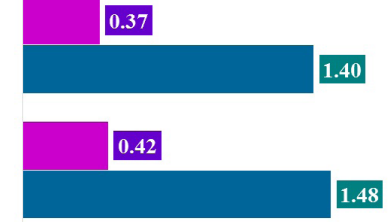

Demographic Status

"Std. Deviation Mean

Source: Author adopted

In figure 3, among 300 respondents participated from eight Islamic countries. This result was correctly gathered by our responsible volunteer team. We randomly picked up open dialogue opportunities in addition to the organized survey. Sometimes, the standardized questionnaire does not adequately expose human lives. Our trustworthy and dedicated volunteer took notes and found them innocuous by openly asking questions. Women's health care was vulnerable during the lockdown, destitute conditions of elderly people, health threats particularly for people with chronic diseases (diabetes, cancer patients), financial crises made relationships vulnerable, and students were thrown away books due to lack of family peace. To divert mind and concentration on computer device games and social networking, snatch the cell phones for long days, juvenile minds experience intense tension and life becomes more monotonous. Eleven suicidal incidents were registered among the eight respondent countries.

Figure 4. Before lockdown consumers buying tendency

\section{CONSUMER IMPULSIVE BUYING INTENTION ON COVID-19 TIME}

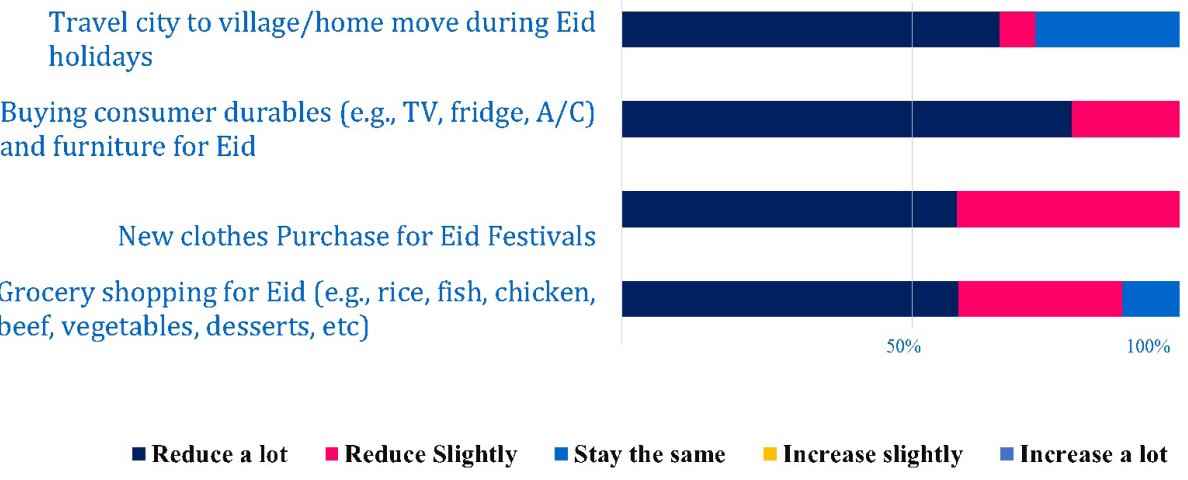

Source: Author adopted, Data Processed 2020.

In figure 4, the time of pandemic people didn't care about this diseases and considered it like other 
diseases. So, $23^{\text {rd }}$ May, 2020 to observe an Eid-Ul-Fitr which is Muslim holiday marking the end of Ramadan (month of fasting). More than 60 percent of peoples agreed not to observe this day at the village home during this pandemic. Even though, due to Covid-19 hazard, Muslim religious people limited to visit at prayer hall (Mosque/Masjid) and not to go outside. Even so, stop Eid celebrated outside the home by world Muslims. 55 percent of people stop purchasing clothes to save money and avoid visiting strangers and relatives house.

Figure 5. Impulsive FMCG Buying Intention of Next 3 Month

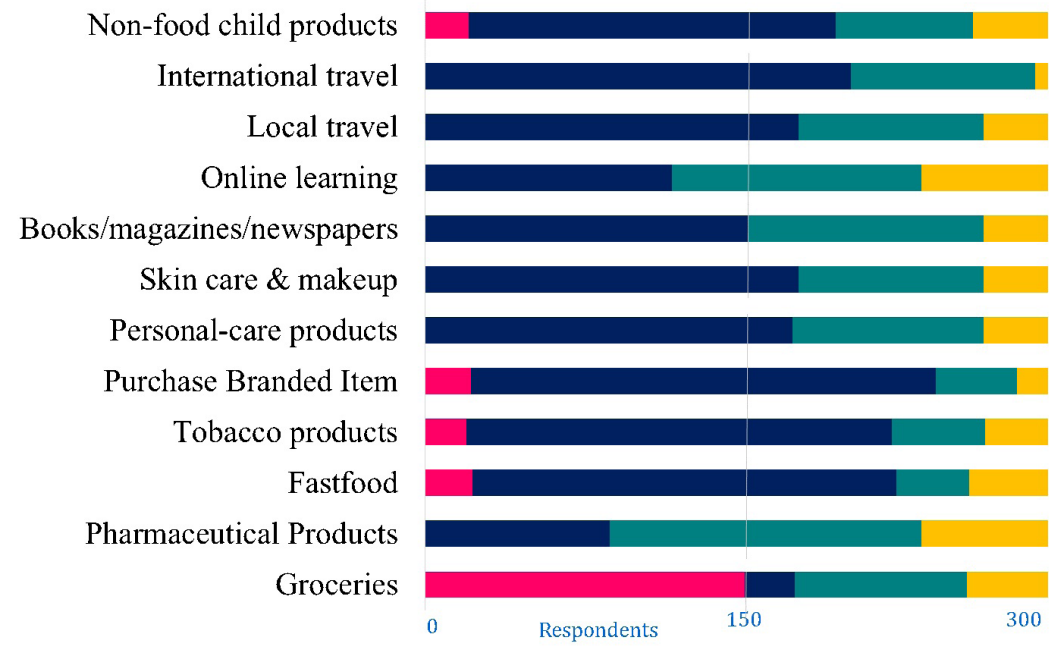

$\square$ More Decrease $\quad$ Decrease $\quad$ Stay the same $\quad$ Increase

Source: Author adopted, Data Processed 2020.

In Figure 5, the pre-lockdown survey began among the Islamic countries on the purchasing intention of the next three months of the pandemic where the purchasing and preserving intentions of fastmoving consumer goods (FMCG) were explored. The percentage number of respondents shared their purchasing intentions.

Figure 6. Media entertainment \& electronic gadget impulsive buying intention of next 3 month

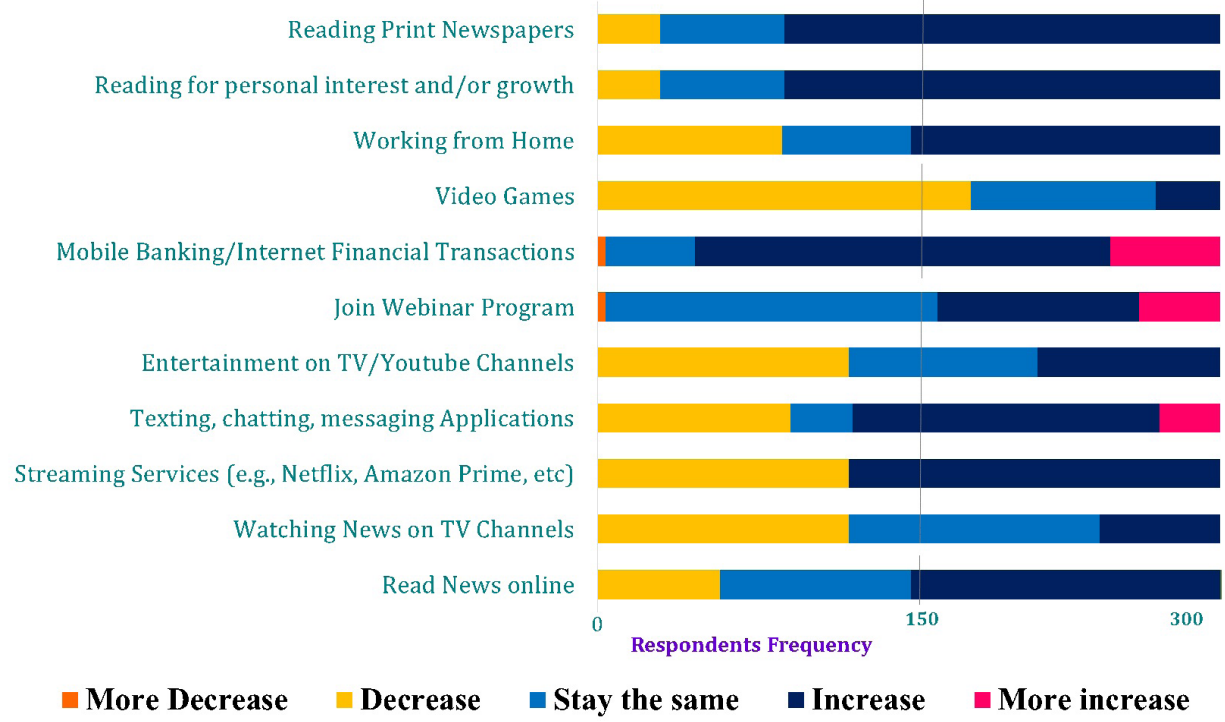

Source: Author adopted, Data Processed 2020. 
In Figure 6, the study revels media entertainment \& electronic gadget impulsive buying intention of next 3 month where ATL \& BTL media consumption and electronic gadget purchasing intention increased. Though, OTT plat form and live streaming media consumption increased.

Figure 7. Personal/Household Finances Will Be Impacted By the Covid-19

\section{HOW LONG DO YOU BELIEVE YOUR \\ PERSONAL/HOUSEHOLD FINANCES WILL BE \\ IMPACTED BY THE COVID-19 SITUATION?}

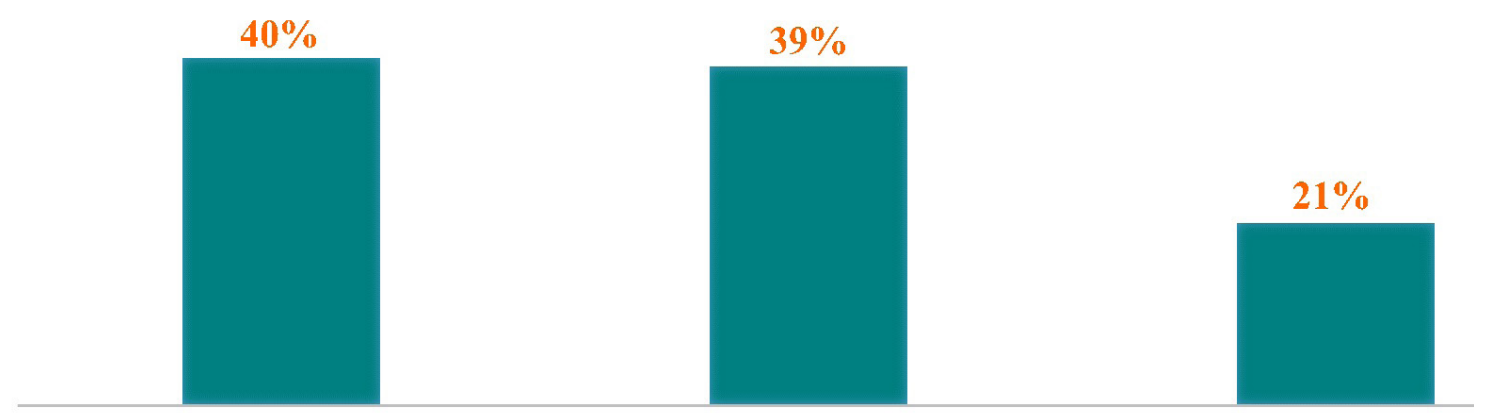

Source: Author adopted, Data Processed 2020.

Figure 7 shows that 40 percent of respondents in the socio-economic class (SEC) C \& D assume that personal and household income will be affected by COVID 19 next year. In comparison, 39\% of SEC-B respondents expected that it will be affected in the next 7 to 12 months. And, $21 \%$ of the SEC-A and elite class expected that their financial income would be impacted in the next 2 to 3 months.

Figure 8. Consumers Purchased Food Tendency throughout the Pandemic

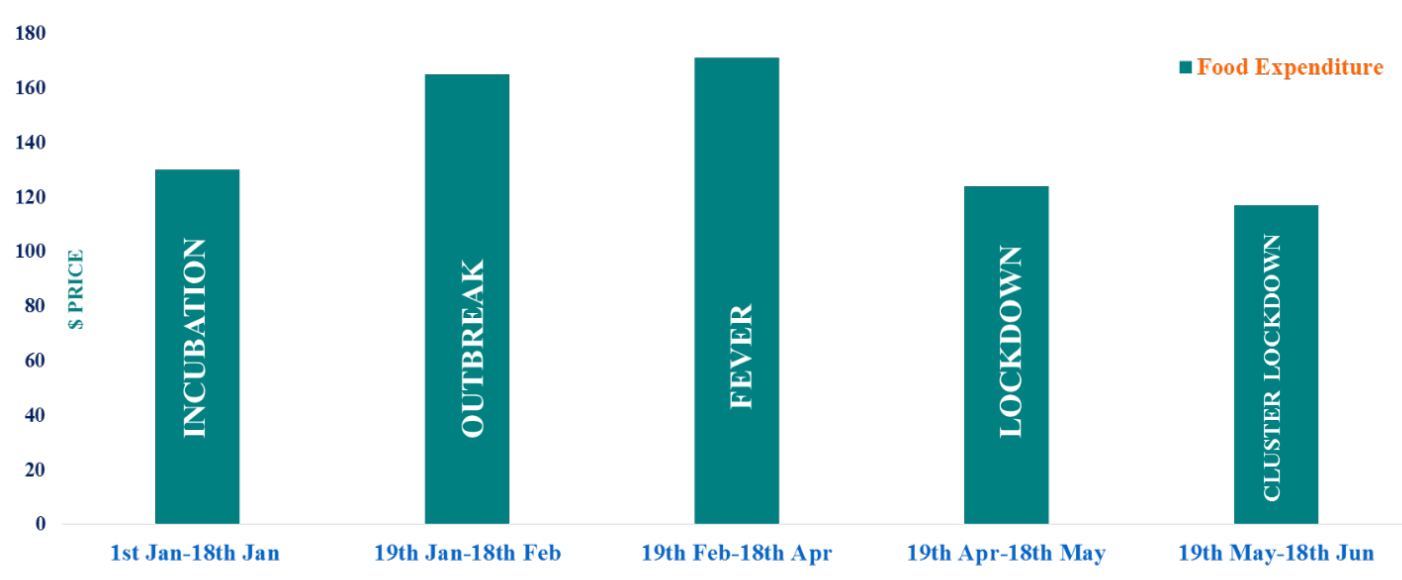

Source: Author Adopted \& Data Processed 2020. Note: price in dollars

In figure 8, lockdown period breakdown with against expense with how much they paid out of each segments. The highest money expense in 'Fever' phase $\left(19^{\text {th }}\right.$ February 2020 to $18^{\text {th }}$ April 2020) whereas overall spent 161 dollar in selected Islamic countries. Lock down and Cluster lock down phases, spent was approximately 120 dollar more on averages. 
Figure 9. The eight Islamic countries respondents spending attitude on grocery delivery services

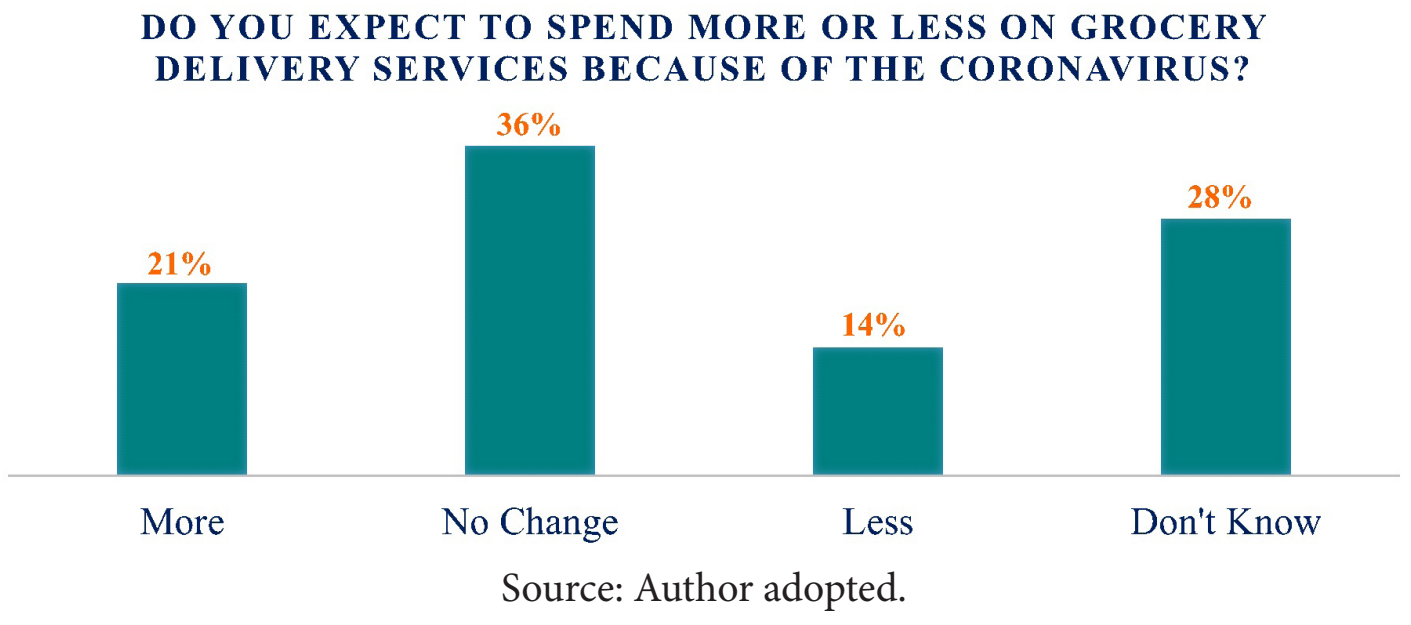

Figure 10. Do you expect to purchase goods from online marketplaces due to coronavirus?

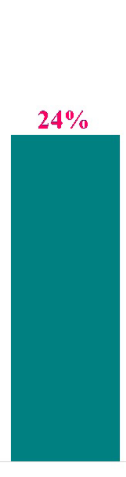

More

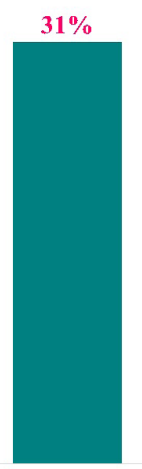

No Change

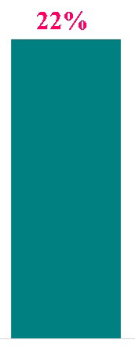

Less

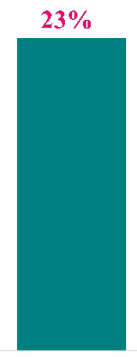

Don't Know

Source: Author Adopted

Figure 11. The consumer share in global food supply stockpiled by country in March 2020.
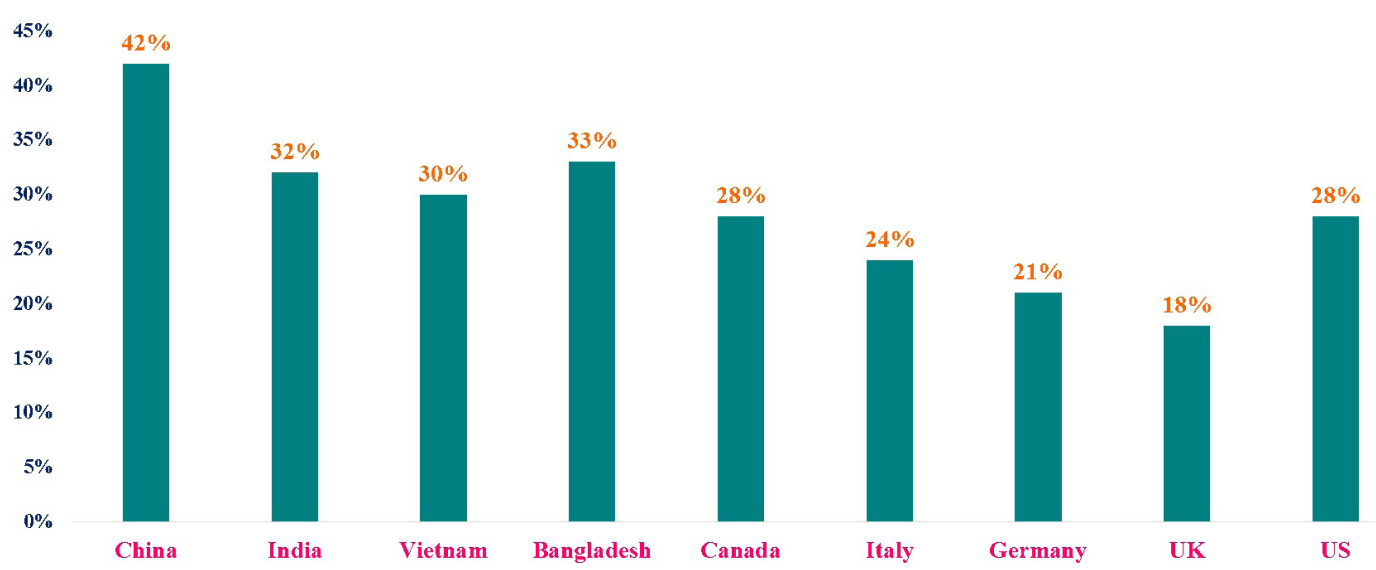

\section{Source: Statista}

The results shows that economy is severely collapsed, financial sector crawling to survive and restart the business supply chain. Consumers become conscious about buying and avoiding unnecessary consumption from their consumption bucket list and food wastage declined in home recent days. Panic buying is a powerful predictor on economy and for the precaution of Covid-19, Muslim 
consumers storage their necessary items and some were unnecessary before lockdown.

In window hours, Muslim consumers' preferring to buy from neighborhood. Media and home entertainment consumption sharply increased. In this study showed that, Millennia's and generation $\mathrm{Z}$ inducing house head to use technology to solve the impulsive buying needs, to ensure health safety. Millennia's and generation $\mathrm{Z}$ are also contributing in decision making about purchasing products from online market store and tending into brand products for product durability. Food inflation has increased inhumanely in Bangladesh, Indonesia, Egypt, Pakistan and Jordan. Predicting, the post Covid-19, situation will be challenging to alleviate this financial gaps and Muslim consumers buying behavior, because everything is interlinked with several parameters. The economic effects will be reflected in the personal and social relationship, education, health, employment, informal and gig economy and impulsive buying patterns behaviors.

\section{RECOMMENDATION}

According to the evaluation of Islamic countries in this study the Covid-19 has immediate disruption of economic activity across the region, as demonstrated by declining tourism, remittance inflows, disrupted air transport, downfall price of crude oil, declining consumer purchasing behavior and business confidence as several countries shut down, community quarantines, and purchase necessary items from online e-commerce market places, temporary closings of companies and restrictions or bans on travel if affected on viruses.

To alleviate the effects of the Covid-19 outbreak by restoring confidence, maintaining economic stability and reviving growth. So we recommended policy for Islamic countries as follows.

First, all kinds of disruptions must be eliminated and all available macro and financial units must be mobilized in accordance with health directives. Because a shortage in the supply chain has seriously affected the Covid-19 epidemic.

Second, policy makers should formulate the economy for a start again with nominal loss of productivity when the protection period ends. The significant amount is to postpone any debt obligations to prevent companies from going through the crisis. This preserves the physical capital of the economy and allows it to be used after the crisis.

Third, Potential trade restrictions, as well as bureaucratic barriers and tax policy options, must be explored to bring producers into contact with the market and consumers. In our study the eight selected Islamic countries must strike a balance between the need to continue production and the protection of people, including consumers and supply chain workers.

Fourth, the social safety nets (SSNs) are essential for poverty decline as they support inclusive growth and provide resources for the most vulnerable in society, especially during times of crisis. Jeopardize employees are more likely to lose their job if they lose their job if they are not available in work. Selected eight Islamic countries policy makers and official need to set rule how to balance this situation. Safety nets, in particular money transfers, paid leaves and health insurance, can provide rapid financial support to reach jeopardize and poor group in the societies.

And finally, the increasing demand for coronaviruses to lift mobility restrictions during a coronavirus pandemic has emphasized the need to take advantage of technology and digital commerce. The transition to a digital platform has helped to reduce the decline in economic productivity, current and future, by facilitating distance learning and working. In addition, social media can be a significant perk, while e-commerce is possibly to grow as consumers avoid brickand-mortar stores and crowded collection points and further increase the use of their own trading channel. To minimize perceived risks, transparent information is required by consumers. 


\section{CONCLUSION}

The main objective of this study was to examine the financial effects on the economy and the impulsive purchasing attitude of the Islamic countries consumers in the Covid-19 pandemic. This research has added new details that enhances our existing limited knowledge of the economic effect measures on the purchasing behavior of consumers in Muslim countries during the pandemic era in Islamic countries. Overall findings from current research, combined with experience in relevant literature, support the recommendation that Muslim consumers purchase their intentions based on religious affiliation, perceived strength, and peer acceptance, assurance of Halal logo and ingredients, internal and external factors. Experts predict that the deadly disease will not leave the world too soon. However, in the meanwhile we may have to survive by following proper hygiene rules. This will be the 'next normal' survival in the economy.

Since the start of the current fiscal year, the Bangladesh, Turkey, Malaysia,, Jordan, Pakistan, KSA and Indonesia economy has faced major challenges in the areas of income mobilization, the banking sector, capital markets, foreign remittance, the RMG sector, gig and informal economy and the exports sector. The Covid-19 pandemic has exacerbated these challenges by affecting the economy through various transmission channels, national and global. This has now been exacerbated momentum by the Amphan super cyclone especially Bangladesh and Indonesia. (Guardian 2020), which has struck the country's coastal zone, causing significant losses to crops, property and costing lives. The spread of the pandemic greatly suffered in Asian Islamic countries and the subsequent negative impacts on "Muslims Eid Holiday (25 ${ }^{\text {th }}$ May 2020)", almost all macroeconomic correlations, and severely crushed on the selected Islamic countries economy specially, traders and buyers. In the last three decades, behavioral approaches have dominated the market dynamics before Covid-19 hit homes and locked us all in. Kotler and Keller (2012) said a good understanding. It is important for the lives of consumers to ensure that the most suitable goods and services are sold in the most successful way possible to the right people. With a new twist that affects healthcare, personal health, and well-being, consumers would be financially affected. It can provide a new incentive for long-term behavior change, indicating a new segment of migrated customers who will become more frugal with a new value of the 'save and stockpile' and change in their purchasing habits. Studies of the values of Asian cultures have specifically recognized the role frugality plays as a guiding principle underlying the actions of consumers (Anderson \& Wadkins, 1991). The pandemic taught us about scrimping and saving attitudes to understand the behavior of proper utilization of limited resources.

\section{Declarations}

Availability of data and materials

Author adopted primary data applied in this study.

\section{Competing interests}

The author declares that he has no competing interests.

\section{Funding}

Not applicable.

Authors' contributions

Not applicable.

\section{Comments}

We are truly gratitude to a good number of enthusiastic volunteers who helped us to make this study positive. 


\section{REFERENCES}

Abdul, Mohani and Ismail, Hashanah and Hashim, Haslina and Johari, Juliana. (2009). Consumer decision making process in shopping for halal food in Malaysia. China-USA Business Review, 8 (9). pp. 40-47. ISSN 1537-1514

Accenture. (2020). COVID-19 will permanently change consumer behavior. Retrieved at https://www.accenture.com/us-en/insights/consumer-goods-services/coronavirusconsumer-behavior-research (accessed at 28.03.2020).

A.E. Gamma, J. Slekiene, H.J. Mosler (2020). The impact of various promotional activities on Ebola prevention behaviors and psychosocial factors predicting Ebola prevention behaviors in the Gambia evaluation of Ebola prevention promotions; Int. J. Environ. Res. Publ. Health, 16 (11) (2020), p. 2020

Ajzen, I. (2011). The theory of planned behavior: Reactions and reflections. Psychology \& Health, 26(9), 1113-1127.

Alam, S. S., Mohd, R., \& Hisham, B. (2011). Is religiosity an important determinant on Muslim consumer behavior in Malaysia? Journal of Islamic Marketing, 2(1), 83-96.

Albelaikhi, A. A. (1988). Religious Orientation and Fear of Death among Muslim and Christian Individuals. University of Rhode Island, Psychology Department, Kingston.

Al-Debei, M. M., Akroush, M. N., \& Ashouri, M. I. (2015). Consumer attitudes towards online shopping. Internet Research, 25(5), 707-733. doi:10.1108/IntR-05-2014-0146

Allport, G. W., and Ross, J.M. (1967). Personal Religious Orientation and Prejudice. Journal of Personality and Social Psychology, 5, 432-443.

Almond, D. (2006). Is the 1918 Influenza Pandemic Over? Long-term Effects of in Utero Influenza Exposure in the Post-1940 US population. Journal of Political Economy, 114(4), 672-712.

Anderson, R. C., Fell, D., Smith, R. L., Hansen, E. N., \& Gomon, S. (2005). Current Consumer behavior research in forest products. Forest Products Journal, 55(1), 21-27.

Anderson, L., \& Wadkins, M. (1991). Japan: A culture of consumption? Advances in Consumer Research, 18, 129-134.

Baker, S. R., Bloom, N., Davis, S. J., Kost, K., Sammon, M., \& Viratyosin, T. (2020b). The Unprecedented Stock Market Reaction to COVID-19 . National Bureau of Economic Research Working Paper, Number 26945.

Bangladesh Bureau of Statistics. (2020). Statistics and informatics division (SID). Retrieved at http://www.bbs.gov.bd/

Beatty, S. E., \& Kahle, L. R. (1988). Alternative hierarchies of the attitude-behavior relationship: The impact of brand commitment and habit. Journal of the Academy of Marketing Science, 16(2), $1-10$.

Berné, C., Múgica, J. M., Pedraja, M., \& Rivera, P. (2001). Factors involved in price informationseeking behavior. Journal of Retailing and Consumer Services, 8(2), 71-84. https://doi.org/https://doi.org/10.1016/S0969-6989 (99)00027-2

Billore, S., \& Anisimova, T. (2021). Panic buying research: A systematic literature review and future research agenda. International Journal of Consumer Studies, Available at: ijcs.12669. doi: https://doi.org/10.1111/ijcs.12669

Bloomberg News. (2020). China's Harbin Tightens Quarantine Measures against Covid-19. Bloomberg.https://www.bloomberg.com/news/articles/2020-04-12/china-s-harbintightens-quarantine-measures-against-Covid-19 .

Brahmbhatt, M., \& Dutta, A. (2008). On SARS Type Economic Effects during Infectious Disease Outbreaks. The World Bank Policy Research Working Paper Number 4466. http://documents.worldbank.org/curated/en/101511468028867410/On-SARS-typeeconomic-effects-during-infectious-disease-outbreaks

Brainerd, E., \& Siegler, M. V. (2003). The Economic Effects of the 1918 Influenza Epidemic. CEPR Discussion Paper Number 3791. 
Burns, A., Mensbrugghe, D., \& Timmer, H. (2006). Evaluating the Economic Consequences of Avian Influenza, in Global Development Finance. The World Bank. , 1(1).

http://documents.worldbank.org/curated/en/977141468158986545/Evaluating-theeconomic-consequences-of-avian-influenza

CFO Insights. (2020). Investor relations: Adapting to the COVID-19 next normal. [Financial Advisory Services]. Deloitte. https://www2.deloitte.com/us/en/pages/finance/articles/cfoinsights-investor-relations-adapting-to-the-Covid-19-next-normal.html(accessed 16.06.2020).

Chen, Y., \& Barnes, S. (2007). Initial trust and online buyer behavior. Industrial Management \& Data Systems, 107(1), 21-36. doi:10.1108/02635570710719034

Chinazzi, M., Davis, J. T., Ajelli, M., Gioannini, C., Litvinova , M., Merler, S., Piontti, A. P., MU, K.,

Rossi, L., SUN, K., \& Viboud, C. (n.d.). The effect of travel restrictions on the spread of the 2019 novel coronavirus (COVID-19 ) outbreak. Science. https://doi.org/10.1126/science.aba9757

Chou, J., Kuo, N.-F., \& Peng, S.-L. (2004). Potential Impacts of the SARS Outbreak on Taiwan's Economy. Asian Economic Papers, 3(1), 84-112.

Chu, M. M. (2020, June 8). Malaysia to reopen most economic activity with virus outbreak 'under control. The Jakarta Post. https://www.thejakartapost.com/seasia/2020/06/08/malaysia-toreopen-most-economic-activity-with-virus-outbreak-under-control.html

Clemens, K. S., Matkovic, J., Faasse, K., \& Geers, A. L. (2020). Determinants of safety-focused product purchasing in the United States at the beginning of the global COVID-19 pandemic. Safety Science, 130, 104894. https://doi.org/10.1016/j.ssci.2020.104894

Cogley, M. (2020).Has social media turbocharged panic buying by UK shoppers? Available at: https://www.telegraph.co.uk/technology/2020/03/10/has-social-media-turbochargedpanic-buying-uk-shoppers/ (2020)

Correia, S., Luck, S., \& Verner, F. (2020). Pandemics Depress the Economy, Public Health Interventions Do Not: Evidence from the 1918 Flu. Stanford Graduate School of Business. https://www.gsb.stanford.edu/sites/gsb/files/fin_04_20_verner.pdf

Crabbe, M. (2020, March 3). Research your way out of a crisis: COVID-19 's effect on consumer behavior. [Marketing Research]. Mintel. https://www.mintel.com/blog/consumer-marketnews/research-your-way-out-of-a-crisis-Covid-19 s-effect-on-consumer-behaviour

Cronbach, L.J. (1951). Coefficient alpha and the internal structure of tests. Psychometrika, Vol. 16. No. 3, pp. 297-334, available at: http://dx.doi.org/10.1007/BF02310555

Davis, F. D. (1989). Perceived usefulness, perceived ease of use, and user acceptance of information technology. MIS Quarterly, 13(3), 319-340.

Delener, N. (1990a). The Effects of Religious Factors on Perceived Risk In Durable Goods. Journal of Consumer Marketing, 7(3) 27.

Dela, G.A. (2020). How social media is shaping our fears of - and response to - the coronavirus Available at: https://time.com/5802802/social-media-coronavirus/ (2020)

Dooley, K. J., Yan, T., Mohan, S., \& Gopalakrishnan, M. (2010). Inventory management and the bullwhip effect during the 2007-2009 recession: Evidence from the manufacturing sector. Journal of Supply Chain Management, 46(1), 12-18.

Dowd, K., \& Burke, K. J. (2013). The influence of ethical values and food chIslamice motivations on intentions to purchase sustainably sourced foods. Appetite, 69, 137-144.

Dunn, K. I., Mohr, P., Wilson, C. J., \& Wittert, G. A. (2011). Determinants of fast-food consumption. An application of the theory of planned behavior. Appetite, 57(2), 349-357.

Dziuban, C.D. and Shirkey, E.C. (1974). When a correlation matrix is appropriate for factor analysis?.

Some decision rules", Psychological Bulletin, Vol. 81 No. 6, pp. 358-361, doi: 10.1037/h0036316.

El Dahshan, M. (2020). How has Egypt navigated the ongoing global economic fallout as a result of COVID-19 ? The Tahrir Institute for Middle East Policy. https://timep.org/commentary/analysis/how-has-egypt-navigated-the-ongoing-globaleconomic-fallout-as-a-result-of-Covid-19/ 
Ellis-Petersen, H., \& Ratcliffe, R. (2020). Super-cyclone Amphan hits coast of India and Bangladesh. The Guardian. https:/www.theguardian.com/world/2020/may/20/super-cyclone-amphanevacuations-in-india-and-bangladesh-slowed-by-virus (Accessed 20 May, 2020).

Emam, A. (2020, March 29). COVID-19 comes with a high cost to Egyptian economy. The Arab Weekly. https://thearabweekly.com/Covid-19-comes-high-cost-egyptian-economy

Evans, O. (2020). Socio-economic impacts of novel coronavirus: The policy solutions. BizEcons Quarterly, 7, 3-12.

FAO. (2013). Food wastage footprint: Impact on natural resources. Summary report. Rome: FAO. . http://www.fao.org/3/i3347e/i3347e.pdf

Feng, C., \& FAY, S. (2020). Store closings and retailer profitability: A contingency perspective. Journal of Retailing. https://doi.org/10.1016/j.jretai.2020.01.002.

Feng, C., \& Fay, S. (2020). Store closings and retailer profitability: A contingency perspective. Journal of Retailing. https://doi.org/10.1016/j.jretai.2020.01.002.

Fernandes, N. (2020). Economic effects of coronavirus outbreak (COVID-19) on the world economy. 1-30. Retrieved at: https://mediaroom.iese.edu/wp-content/uploads/2020/03/FernandesNuno_20200322-Global-Recession-is-inevitable.pdf (Accessed March, 2020).

Fornaro, L., \& Wolf, M. (2020). Covid-19 Coronavirus and Macroeconomic Policy: Some Analytical Notes. London: Center for Economic Policy Research. https://cepr.org/active/publications/discussion_papers/dp.php?dpno=14529

Foxall, G. R. (1979). Industrial Buying During Recession: Farmers' Tractor Purchases, 1977-78. Management Decision, 17(4), 317-325

Garrett, T. (2008). Pandemic Economics: The 1918 Influenza and its Modern-Day Implications. Federal Reserve Bank of St. Louis Review, 90(2), 75-93.

Garrett, Thomas A. (2006) "War and Pestilence as Labor Market Shocks: U.S. Manufacturing Wage Growth 1914-1919." Working Paper 2006-018C, Federal Reserve Bank of St. Louis, 2006. Forthcoming in Economic Inquiry. Available at: https://files.stlouisfed.org/files/htdocs/publications/review/08/03/Garrett.pdf

Guimbeau, A., Menon, N., \& Musacchio, A. (2020). The Brazilian Bombshell? The Long-Term impact of the 1918 Influenza Pandemic the South American Way. National Bureau of Economic Research Working Paper. https://www.nber.org/papers/w26929

Gustavsson, J., Cederberg, C., Sonesson, U., Otterdijk, R. V., \& Meybeck, A. (2011). Global food losses and food waste. Extent, causes and prevention. Rome: FAO. Food and Agriculture Organization. https://www.fao.org/3/a-i2697e.pdf (Accessed 10 March 2020).

Hai, W., Z. Zhao, Wang, J., Hao, Z-G. (2004). the Short-Term Impact of SARS on the Chinese Economy. Asian Economic Papers 3(1), 57-61.

Hajj 2020: The economic impact of the Saudi ban on international pilgrims. (2020, June 24). TRT World.https://www.trtworld.com/magazine/hajj-2020-the-economic-impact-of-the-saudiban-on-international-pilgrims-37520

Hanudin Amin Abdul-Rahim Abdul-Rahman Dzuljastri Abdul Razak , (2014),"Theory of Islamic consumer behaviour", Journal of Islamic Marketing, Vol. 5 Iss 2 pp. 273 - 301 Permanent link to this document: http://dx.doi.org/10.1108/JIMA-06-2013-0042

Heckhausen, H., Gollwitzer, P., 1987. Thought contents and cognitive functioning in motivational versus volitional states of mind. Motiv. Emot. 11 (2), 101-120.

http://dx.doi.org/10.1007/bf00992338.

Hedgecoe, G., Lowen, M., Williamson, L., Hill, J., Holligan, A., Thorpe, N., De, Launey, G., B., Savage, M., \& Bateman, T. (2020). Coronavirus capital by capital: How are Europeans coping with shutdown? BBC News.

https://www.bbc.co.uk/news/world-europe-52025553 (accessed 26th March 2020).

Hofstede, G. (2001). Culture's consequences: Comparing values, behaviors, institutions and organizations across nations. Tilburg: SAGE Publications.

Hofstede, G., Hofstede, G. J., \& Minkov, M. (2010). Cultures and Organizations: Software of the Mind. New York: McGraw-Hill. Available at: 
https://www.mintel.com/blog/consumer-market-news/the-next-normal-is-now (Accessed 09.06.2020).

Indonesia braces for bad times, up to 5.2 million may lose jobs. (2020, April 16). New Straits Times. https://www.nst.com.my/world/region/2020/04/584847/indonesia-braces-bad-times-52million-may-lose-jobs

Iyer, E.S., 1989. Unplanned purchasing: knowledge of shopping environment and time pressure. Journal of Retailing 65 (1), 40-57.

Jordan's tourism revenues drop by $10.7 \%$ in Q1 2020-CBJ. (2020, June 1). The Jordan Times. https://www.zawya.com/mena/en/economy/story/Jordans_tourism_revenues_drop_ by_107_in_Q1_2020_CBJ-SNG_175882676/

Karlsson, M., Nilsson, T., \& Pichler, S. (2014). The Impact of the 1918 Spanish flu Epidemic on Economic Performance in Sweden: An Investigation into the Consequences of an Extraordinary Mortality Shock. Journal of Health Economics, 36, 1-19.

Karlsson, M., Nilsson, T., \& Pichler, S. (2014). The Impact of the 1918 Spanish flu Epidemic on Economic Performance in Sweden: An Investigation into the Consequences of an Extraordinary Mortality Shock. Journal of Health Economics, 36, 1-19.

Keane, M., \& Neal, T. (2021). Consumer panic in the COVID-19 pandemic. Journal of Econometrics, 220(1), 86-105. https://doi.org/10.1016/j.jeconom.2020.07.045

Keogh-Brown, M. R., \& Smith, R. D. (2008). The Economic Impact of SARS: How Does the Reality Match the Predictions? Health Policy, 88(1), 110-120.

Kostova, D., Cassell, C.H., Redd, J. T., Williams, D. E., Singh, T., Martel, L.D., \& Bunnell, R.E. (2019.). Long- distance effects of epidemics: Assessing the link between the 2014 West Africa Ebola outbreak and U.S. exports and employment. Health Economics, 28, 1248-1261.

Kirk, C. P., \& Rifkin, L. S. (2020). I'll trade you diamonds for toilet paper: Consumer reacting, coping and adapting behaviors in the COVID-19 pandemic. Journal of Business Research, 117, 124-131. Doi: https://doi.org/10.1016/j.jbusres.2020.05.028

Lamming, R. (2000). Japanese supply chain relationships in recession. Long Range Planning, 33(6), 757-778

Laato, S., Islam, A. N., \& Laine, T. H. (2020). Did location-based games motivate players to socialize during COVID-19 ? Telematics and Informatics, 54, 101458.

Laato, S., Islam, A. K. M. N., \& Laine, T. H. (2020). Did location-based games motivate players to socialize during COVID-19 ? Telematics and Informatics, 54, 101458. https://doi.org/10.1016/j.tele.2020.101458

Leduc, S., \& Liu, Z. (2020, March 30). The Uncertainty Channel of the Coronavirus, Federal Reserve Bank of San Francisco Letter, Number 2020-07. https://www.frbsf.org/economic-research/ publications/economic-letter/2020/march/uncertainty-channel-of-coronavirus/

Lee, J., \& McKibbin, W. (2004). Globalization and Disease: The Case of SARS. . Asian Economic Papers, 3(1), 113-131.

Liu, J.-T., Hammitt, J. K., Wang, J.-D., \& Tsou, M.-W. (n.d.). Valuation of the risk of SARS in Taiwan. Health Economics, 14, 83-91.

Mathieson, K. (1991). Predicting user intentions: comparing the technology acceptance model with the theory of planned behavior. Information systems research, 2(3), 173-191.

Mahmood, M. (2020, June 13). Covid-19 : Economic challenges facing Bangladesh. The Financial Express. https://thefinancialexpress.com.bd/views/Covid-19 -economic-challenges-facingbangladesh-1592064588

McIntosh, M. (2020). How 2020's Oil Prices Will Challenge Saudi Arabian Economic Diversification. Atlas Institute for International Affairs. https://www.internationalaffairshouse.org/how2020s-oil-prices-will-stall-saudi-arabian-economic-diversification/

McKibbin, W., Fernando, R. (2020a). The Global Macroeconomic Impacts of COVID-19 : Seven Scenarios, Washington: Brookings Institution. 
Meltzer M.I., Cox N.J, Fukuda K. (1999). The economic impact of pandemic influenza in the UnitedStates: priorities for intervention. Emerging Infectious Disease, 5(5), 659-71

Mogelonsky, Marcia (2020). The 'Next Normal' Is Now. Mintel.

Naeem, M. (2020). Do social media platforms develop consumer panic buying during the fear of Covid-19 pandemic? Journal of Retailing and Consumer Services, 58, 102226.

Naeem, M. (2021). Do social media platforms develop consumer panic buying during the fear of Covid-19 pandemic. Journal of Retailing and Consumer Services, 58, 102226. Doi: https://doi.org/10.1016/j.jretconser.2020.102226

Mukit, M. M. H. (2020). An econometric analysis of the macroeconomic determinants impact of gross domestic product (GDP) in Bangladesh. Atlantic Review of Economics, 3(2). http://aroec.org/ojs/index.php/ARoEc/article/view/120

Mukit, M. M. H., Nabila, N. J., Islam, M. S., \& Abdel-Razzaq, A. I. (2020). Valuing women entrepreneurship in the informal economy in Bangladesh. Economics, 8(2), 37-54. Oikos Institute - Research Centre. doi: https://doi.org/10.2478/eoik-2020-0020 ; Retrieved at: http://economicsrs.com/index.php/economicus/article/view/178

Murphy, C. et. al. (2020, March). Corona-virus \& Behavior Change. [Data Supplier]. www.Ipsos.com; IPSOS.

https://www.ipsos.com/sites/default/files/ct/publication/documents/ 2020-03/coronavirus-behavior-change-ipsos.pdf (accessed March, 2020)

_OECD. (2020). OECD Economic Outlook-June 2020: The world economy on a tightrope. https://www.oecd-ilibrary.org/

Povera, A., Harun, H. N., \& Arumugam, T. (2020, May 1). Malaysia has suffered RM63 billion losses due to MCO. New Straits Times.

https://www.nst.com.my/news/nation/2020/05/588982/pm-malaysia-has-suffered-rm63billion-losses-due-mco

Pruett, M. (2020, March 25). Coronavirus Consumer Trends: Consumer Electronics, Pet Supplies, and More [Commerce Marketing]. Criteo. https://www.criteo.com/insights/coronavirus-consumer-trends/

Puccinelli, N., Goodstein, R., Grewal, D., Price, R., Raghubir, P., \& Stewart, D. (2009). Customer experience management in retailing: Understanding the buying process. Journal of Retail, 85(1), 15-30. https://doi.org/ http://dx.doi.org/10.1016/j.jretai.2008.11.003.

Rassy, D., \& Smith, R. D. (2013). The Economic Impact of H1N1 on Mexico's Tourist and Pork Sectors. Health Economics, 22, 824-834.

Saeedi, T. A. (2020, May 2). Consumer inflation falls to 8-month low of 8.5 percent. The News. https://www.thenews.com.pk/print/652706-consumer-inflation-falls-to-8-month-low-of8-5-percent

Saudi Arabia closes schools over coronavirus concerns. (2020, March 9). ARAB NEWS. https://www.arabnews.com/node/1638606/saudi-arabia

Selva Demiralp. (2020). the economic impact of COVID-19 on Turkey. Middle East Institute. https://www.mei.edu/publications/economic-impact-Covid-19-turkey

Sood, J., and Nasu Y. (1995). Religiosity and Nationality: An Exploratory Study of their effects on Consumer Behavior in Japan and The United States. Journal of Business Research 34, 1-9.

Suki, N. M. (2014). Does celebrity credibility influence Muslim and non-Muslim consumers' attitudes toward brands and purchase intention? Journal of Islamic Marketing, 5(2), 227240.

Taylor, J. W. (1974). The role of risk in consumer behavior: A comprehensive and operational theory of risk taking in consumer behavior. Journal of Marketing, 38(2), 54-60

Thakor, M., \& Prajapati, S. G. (2012). Factors that encourage impulse purchase and impact of visual merchandising on the purchase decision of women for beauty product in Gujrat. . International Journal of Research in Commerce, Economics and Management, 2(9), 7-11. 
The Central Bank of Jordan announces a set of procedures aimed to contain the repercussions of the emerging Corona virus impact on the national economy. (2020). the Central Bank of J ordan (CBJ). https://www.cbj.gov.jo/DetailsPage/CBJEN/NewsDetails.aspx?ID=279

Thomas, A., \& Garland, R. (2004). Grocery shopping: List and non-list usage. Marketing Intelligence \& Planning, 22(6), 623-635. https://doi.org/http://dx.doi.org/10.1108/02634500410559015.

Wang, E., An, N., Gao, Z., Kiprop, E., \& Geng, X. (2020). Consumer food stockpiling behavior and willingness to pay for food reserves in COVID-19 . Food Security, 12(4), 739-747. https://doi.org/10.1007/s12571-020-01092-1

V., Rashmi. (2014). Study on impulse buying behavior of fashion-oriented Indian youth with respect to visual merchandising. . International Journal of Management and Social Science Research Review, 1(4), 235-239.

Verma, P., \& Verma, R. . (2012). an on-field-survey of the impulse buying behaviour of consumers in consumer non-durable sectors in the retail outlets in the city of Indore, India. Research Journal of Management Sciences, Vol. 1(4), 1-5. . India. Research Journal of Management Sciences, 1(4), 1-5.

Vishnu, P., \& Raheem, A. R. (2013). Factors influencing impulse buying behavior. European Journal of Scientific Research, 100(3), 67-79.

World Health Organization (WHO). (2020). Corona virus disease (COVID-19) Pandemic. Retrieved at: https://www.who.int/docs/default-source/coronaviruse/situation-reports/ 20200410-sitrep-81-Covid-19.pdf? Sfvrsn=ca96eb84_2. (Accessed 10 April, 2020).

Yadav, R., \& Pathak, G. S. (2016). Young consumers' intention towards buying green products in a developing nation: Extending the theory of planned behavior. Journal of Cleaner Production, $135,732-739$. 